\title{
Trimethoprim resistance determinants encoding a dihydrofolate reductase in clinical isolates of Staphylococcus aureus and coagulase-negative staphylococci
}

\author{
JAN M. TENNENT*, HILARY-KAY YOUNGt‡, B. R. LYON, S. G. B. AMYESt and R. A. \\ SKURRAY
}

Department of Microbiology, Monash University, Clayton, Victoria 3168, Australia and TDepartment of Bacteriology, Medical School, University of Edinburgh, Edinburgh EH8 9AG

\begin{abstract}
Summary. The molecular and biochemical basis of resistance to high concentrations $(\mathrm{MIC} \geqslant 1000 \mathrm{mg} / \mathrm{L})$ of trimethoprim $\left(\mathrm{Tp}^{\mathrm{r}}{ }_{(\mathrm{H})}\right)$ was examined in Australian isolates of Staphylococcus aureus and coagulase-negative staphylococci. The $\operatorname{Tp}^{r}{ }_{(\mathrm{H})}$ determinant $(d f r A)$ was located within a $2 \cdot 75-\mathrm{Kb} B g l \mathrm{II}$ fragment on the $S$. aureus aminoglycosideresistance plasmids pSK 1 and pSK 16 as judged by comparative restriction mapping with two naturally-occurring variants, pSK9 and pSK14, which did not encode trimethoprim resistance. This was confirmed in DNA-DNA hybridisation experiments in which a $0 \cdot 9-\mathrm{Kb}$ sequence of $\mathrm{pSK} 1 \mathrm{DNA}$ was used as a specific probe for the $\mathrm{Tp}^{\mathrm{r}}{ }_{(\mathrm{H})}$ gene. Plasmid DNA from three strains of coagulase-negative staphylococci, and the chromosomal material of one other isolate, were found to share homology with the probe DNA. Dihydrofolate reductases produced by these strains were virtually identical to the type S1 enzyme encoded by the $S$. aureus plasmid pSK1. Interspecies transfer may have been responsible for the conservation of $\mathrm{Tp}^{\mathrm{r}}{ }_{(\mathrm{H})}$ gene sequences among staphylococci.
\end{abstract}

\section{Introduction}

Trimethoprim inhibits chromosomally-encoded dihydrofolate reductase (DHFR) required for bacterial metabolism of folic acid (Smith and Amyes, 1984). High-level plasmid-mediated resistance to trimethoprim $\left(\mathrm{Tp}^{\mathrm{r}}{ }_{(\mathrm{H})}\right)$ in Escherichia coli involves the production of an insusceptible target enzyme which allows the inhibited metabolic step to be bypassed (Amyes and Smith, 1974). Resistance to trimethoprim has also been encountered in multiresistant strains of Staphylococcus aureus (MRSA) and coagulase-negative staphylococci isolated in Australia and elsewhere (Hamilton-Miller et al., 1981; Lyon et al., 1983; Richardson, 1983; Town-

Received 23 Mar. 1987; revised version accepted 15 Oct. 1987 * Present Address: Department of Microbiology, University of Ume̊a, S-901 87 Ume̊a, Sweden.

¥ Present Address: Department of Molecular and Life Sciences, Dundee College of Technology, Dundee DD1 1HG, United Kingdom.

Correspondence and requests for offprints should be sent to $\mathrm{Dr}$ R. A. Skurray, Department of Microbiology, Monash University, Clayton, Victoria, 3168, Australia. send et al., 1984; Archer et al., 1986). Resistance to high concentrations of trimethoprim $(\geqslant 1000$ $\mathrm{mg} / \mathrm{L})$ in $c .50 \%$ of Australian isolates of MRSA is mediated by the $28 \cdot 4-\mathrm{Kb}$ plasmid $\mathrm{pSK} 1$ which also encodes resistance to acriflavine, quaternary ammonium compounds and the aminoglycosides gentamicin, tobramycin and kanamycin (Gillespie $e t$ al., 1986; Lyon et al., 1987). The trimethoprimresistance gene from pSK 1 , designated $d f r A$ (Lyon and Skurray, 1987), encodes the production of a trimethoprim-resistant dihydrofolate reductase (Young et al., 1987). This plasmid-encoded enzyme, the first to be characterised in staphylococci, differs from all previously characterised plasmid-encoded dihydrofolate reductases and we have designated it type S1 (Young et al., 1987).

The spread of resistance to antimicrobial agents in nature may be accomplished by the transfer of resistance determinants between $S$. aureus and coagulase-negative staphylococci (Lacey, 1975). In continuance of our investigations into the relevance of this hypothesis to the emergence and spread of MRSA in Australian hospitals (Tennent et al., 1984, 1986), we have compared the genetic and 
molecular characteristics of the trimethoprim resistance exhibited by epidemiologically-related isolates of MRSA and coagulase-negative staphylococci and have characterised the trimethoprimresistant dihydrofolate reductases produced by these strains.

\section{Materials and methods}

\section{Bacterial strains and plasmids}

Clinical isolates of $S$. aureus and coagulase-negative staphylococci were selected from a collection of multiresistant strains obtained from Australian hospitals between 1979 and 1982. The coagulase-negative staphylococci were identified as either $S$. epidermidis (114 strains) or as 'other coagulase-negative staphylococci' $(S$. haemolyticus, $S$. saprophyticus, $S$. simulans, $S$. warneri, $S$. hominis; 50 strains) on the basis of phosphatase activity and aerobic production of acid from maltose, mannitol, sucrose, or trehalose (Kloos and Schleifer, 1975). Two strains of 'other coagulase-negative staphylococci' that were highly resistant to trimethoprim were identified as $S$. hominis type I by the API Staph system.

$S$. aureus strains carrying plasmids for use as size standards, and plasmid-free strains of $S$. aureus (SA113, SK982) used as recipients in DNA transfer experiments, have been described previously (Lyon et al., 1984b; Tennent et al., 1986). A description of the $S$. aureus plasmids and strains examined in this study is presented in table I; plasmid pSK 1 is representative of a family of $S$. aureus multiresistance plasmids which range in size from 20 to $42 \mathrm{~Kb}$ and principally encode resistance to antiseptics or disinfectants and to aminoglycoside antibiotics (Gillespie et al., 1987b). Methods for the curing of plasmids and for the construction of the $S$. aureus-E. coli hybrid plasmid pSK 407 from pSK1 have been described elsewhere (Lyon et al., 1983 and 1986).

\section{General procedures}

Trimethoprim sensitivity and minimum inhibitory concentrations (MICs) were determined on Diagnostic Sensitivity Test Agar (Oxoid) supplemented with 5\% defibrinated horse blood lysed with saponin. The methods used for testing sensitivity to other antimicrobial agents, for transformation of plasmid DNA, and for plasmid elimination, were as described previously (Lyon et al., 1983; Gillespie et al., 1984). The transfer of plasmid DNA in mixed culture was performed as described by McDonnell et al. (1983).

\section{DNA manipulation procedures}

Isolation of plasmid DNA, digestion with the restriction enzymes BglII, EcoRI, EcoRV, HindIII, and HpaII (New England Biolabs, Inc., Beverley, MA, USA), and agarose gel electrophoresis, were performed as previously described (Tennent et al., 1984). HindIII digests of lambda DNA were used as standards; fragment sizes in kilobase pairs $(\mathrm{Kb})$ were as published (Daniels et al., 1983). DNA was transferred to nitrocellulose for hybridisation analysis by the bidirectional procedure of Smith and Summers (1980).

A 0.9-Kb EcoRI-EcoRV DNA fragment, which spans the $d f r A$ structural gene, was prepared by electroelution from pSK 407, nick-translated with $\left(\alpha^{-32} \mathrm{P}\right)$ dATP $(1800 \mathrm{Ci} / \mathrm{mmol})$ and hybridised under conditions of high stringency with nitrocellulose filters carrying target DNA, as described by Maniatis et al. (1982). Washed and dried filters were exposed to Fuji $\mathrm{RX}$ film at $-70^{\circ} \mathrm{C}$ for sufficient time to produce an acceptable autoradiograph.

\section{Dihydrofolate reductase}

DHFR was prepared from 3-L stationary-phase cultures grown in Brain Heart Infusion Broth (Oxoid) by the method of Young et al. (1987). Enzyme activity was assayed by the method of Amyes and Smith (1974) and characterised as described previously (Young et al., 1987).

\section{Results}

\section{Trimethoprim resistance in $S$. aureus}

Susceptibility tests of clinical strains of $S$. aureus revealed that plasmids in the same family as pSK 1 , such as pSK16, also conferred high-level resistance to trimethoprim (MIC $>1000 \mathrm{mg} / \mathrm{L}$ ) on their hosts (table I). Derivatives cured of pSK1 (strain SK 553) or pSK16 (strain SK296) were no longer highly resistant to trimethoprim but were more resistant than $S$. aureus NCTC 6571. The level of trimethoprim resistance in SK553 was similar to that found with the clinical isolates of $S$. aureus that carried plasmids pSK9 and pSK14, and $S$. aureus strain SK434 that lacked a plasmid belonging to the pSK 1 family (table I).

\section{Plasmid location of the trimethoprim-resistance gene} in $S$. aureus

The structural gene for $\mathrm{Tp}_{(\mathrm{H})}^{\mathrm{r}}$ which has been localised to a $0 \cdot 75-\mathrm{Kb}$ sequence of DNA contained within the $2 \cdot 75-\mathrm{Kb} B g l \mathrm{II}$ fragment of pSK1 (Lyon et al., 1986) is shown in fig. 1. The $S$. aureus aminoglycoside-resistance plasmids pSK9 and pSK14 did not encode the $\mathrm{Tp}_{(\mathrm{H})}^{\mathrm{r}}$ phenotype although their resistance profiles were similar to those of pSK1 and pSK16 (table I). Digestion of the $\mathrm{Tp}^{\mathrm{r}}{ }_{(\mathrm{H})}$ plasmid pSK 16 with $B g I I \mathrm{I}$ showed that, like pSK 1 , it possessed a $2 \cdot 75-\mathrm{Kb} B g / \mathrm{II}$ fragment (fig. $2 \mathrm{~A}$, lanes $\mathrm{b}$ and e) whereas plasmids pSK9 and pSK 14 (fig. 2A, lanes c and d) did not. Further restriction endonuclease analyses showed that 
Table I. Characteristics of $S$. aureus strains and plasmids

\begin{tabular}{|c|c|c|c|c|}
\hline $\begin{array}{l}S . \text { aureus } \\
\text { strain }\end{array}$ & $\begin{array}{c}\text { MIC of Tp } \\
(\mathrm{mg} / \mathrm{L})\end{array}$ & Plasmid* & $\begin{array}{l}\text { Plasmid } \\
\text { size }(K b)\end{array}$ & Plasmid resistance pattern \\
\hline SK429 & $>1000$ & pSK1 & $28 \cdot 4$ & Gm Tm Km Ac Eb Qa Tp $p_{(H)}$ \\
\hline SK 529 & 1000 & pSK 1 & $28 \cdot 4$ & Gm Tm Km Ac Eb Qa Tp $\mathrm{p}_{(\mathrm{H})}$ \\
\hline SK271 & $>1000$ & pSK 16 & $35 \cdot 1$ & Gm Tm Km Ac Eb Qa Tp $\mathrm{p}_{(\mathrm{H})} \mathrm{Pc}$ \\
\hline SK 257 & 20 & pSK9 & $25 \cdot 7$ & $\mathrm{Gm} \mathrm{Tm} \mathrm{Km} \mathrm{Ac} \mathrm{Eb} \mathrm{Qa}$ \\
\hline SK 74 & 20 & pSK 14 & $24 \cdot 4$ & Gm Tm Km Ac Eb Qa \\
\hline SK $553 \dagger$ & 20 & $\ldots$ & $\ldots$ & $\ldots$ \\
\hline SK296‡ & 20 & $\ldots$ & $\ldots$ & $\ldots$ \\
\hline SK $434 \S$ & 20 & $\ldots$ & $\ldots$ & $\ldots$ \\
\hline NCTC 6571 & $1 \cdot 25$ & $\ldots$ & $\ldots$ & $\ldots$ \\
\hline
\end{tabular}

$\mathrm{Gm}$; gentamicin; Tm, tobramycin; Km, kanamycin; Ac, acriflavine; Eb, ethidium bromide; Qa, quaternary ammonium compounds; $\mathrm{Tp}_{(\mathrm{H})}$, trimethoprim $(\mathrm{MIC} \geqslant 1000 \mathrm{mg} / \mathrm{L}) ; \mathrm{Pc}$, penicillin

* Some strains carry more than one plasmid; only the pSK 1-family plasmid is described.

† SK 553 is a pSK 1-cured derivative of SK 529.

$\ddagger$ SK 296 is a pSK16-cured derivative of SK271.

$\S$ SK434 is a clinical isolate which lacks a pSK 1 -family plasmid.

plasmids pSK9 and pSK 14 were identical to pSK1 except that deletions of $2.7 \mathrm{~Kb}$ and $4.0 \mathrm{~Kb}$, respectively, had occurred in the region of these plasmids corresponding to the position of the $d f r A$ gene (fig. 1). Both deletions were found to overlap the BglII site at 12.05 on the pSK1 map and thus accounted for the distinct $B g$ III profiles of pSK9 and pSK14.

A $0.9-\mathrm{Kb} E c o \mathrm{RI}-E c o \mathrm{RV}$ fragment of plasmid pSK 407 (Lyon et al., 1986), which maps between co-ordinates 13.55 and 14.45 on the pSK1 map (fig. 1) and consists almost entirely of the $d f r A$ determinant, was used to probe the $B g l$ II digests of the $S$. aureus plasmids. Strong hybridisation signals were obtained between the probe and the $2 \cdot 75-\mathrm{Kb}$ BglII fragments of plasmids pSK1 and pSK16 (fig. 2B, lanes $b$ and e). Similarly-sized $B g l I I$ restriction fragments from three other plasmids, pSK 4, pSK8 and $\mathrm{pSK} 17$ found in clinical isolates of $S$. aureus that were highly resistant to trimethoprim (Gillespie $e$ al., 1987b), also demonstrated homology with the probe DNA (data not shown). In contrast, the pSK 407-derived probe did not hybridise with any fragments of pSK9 or pSK 14 (fig. 2B, lanes $\mathrm{c}$ and d), thus confirming the absence of $d f r A$ sequences on these plasmids as suggested by the restriction mapping data. On the basis of these results, the $0 \cdot 9$ -

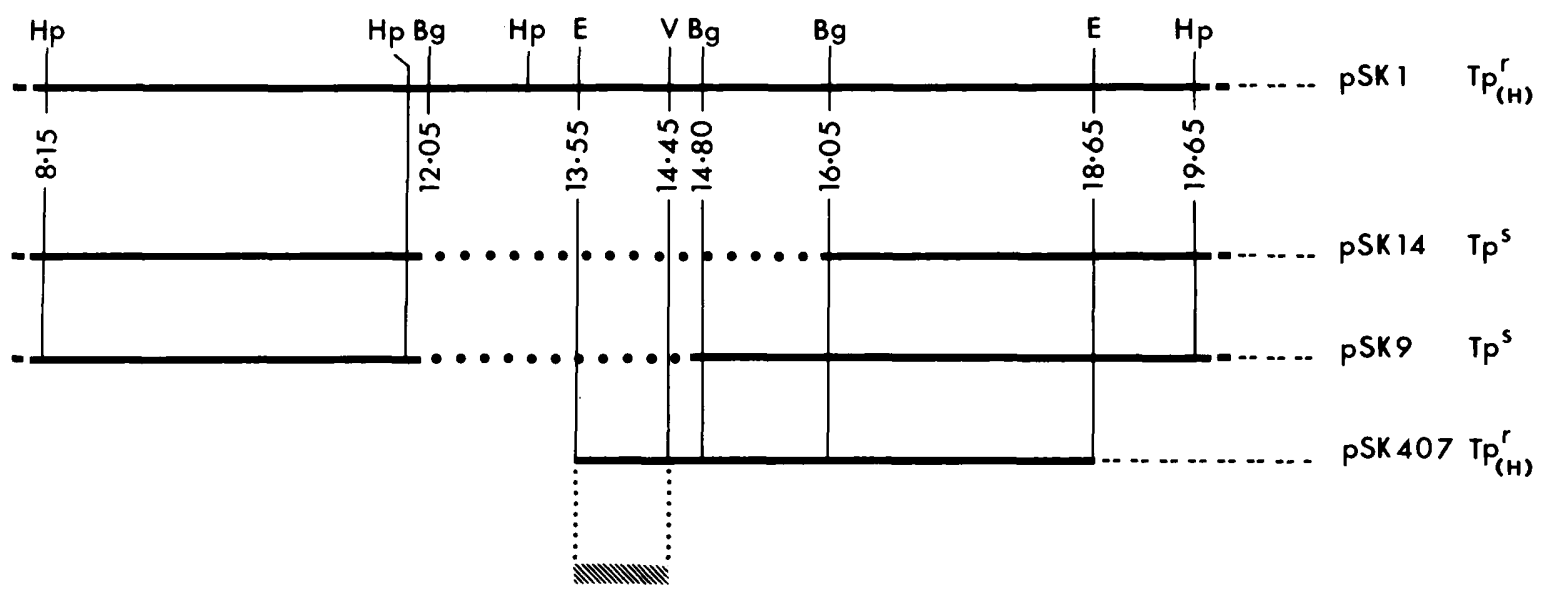

Fig. 1. Restriction endonuclease map of the $\mathrm{Tp}^{\mathrm{r}}{ }_{(\mathrm{H})}$ region of pSK1, together with the corresponding regions of pSK9 and pSK14. Also shown is the location of the $5 \cdot 1-\mathrm{Kb}$ EcoRI fragment of pSK 1 cloned in the formation of pSK 407 . Areas of pSK 1 absent from pSK 9 and pSK 14 are indicated by dotted lines; the hatched region represents the extent of the 0.9-Kb EcoRI-EcoRV hybridisation probe derived from pSK 407 (see text). Map co-ordinates are in $\mathrm{Kb}$; restriction endonuclease sites are indicated by $\mathrm{Bg}(B g / \mathrm{II})$, $\mathrm{E}(E c o \mathrm{RI}), \mathrm{Hp}(H p a \mathrm{II})$ and $\mathrm{V}(E c o \mathrm{RV})$. A complete map of pSK 1 has appeared elsewhere (Lyon et al., 1986). 


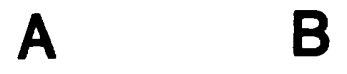

$a b c d e a b c d e$

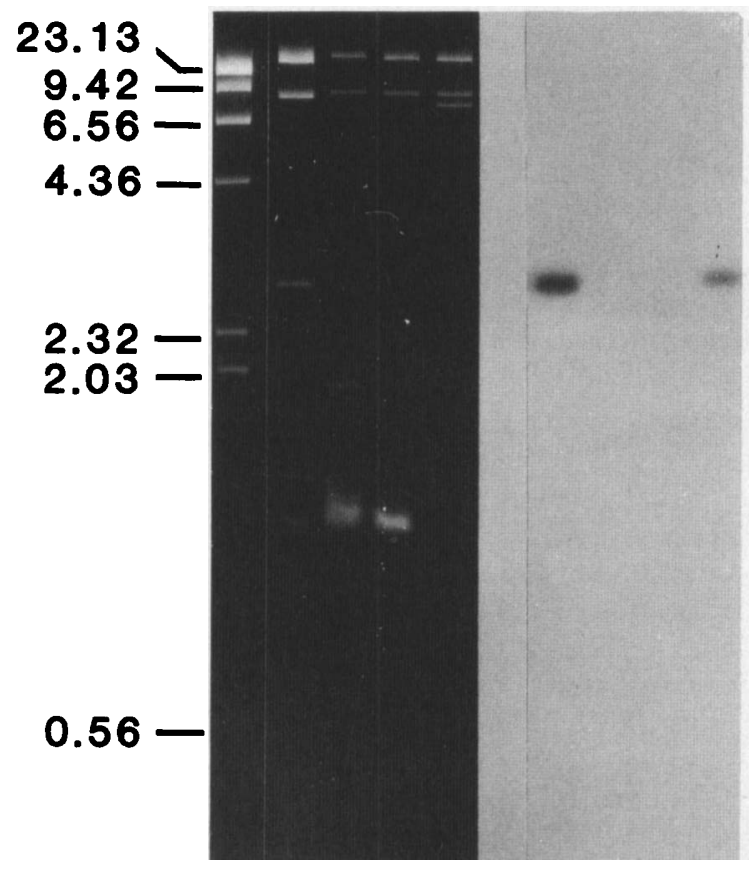

Fig. 2. A. Agarose gel $(1 \cdot 4 \% \mathrm{w} / \mathrm{v})$ electrophoresis of purified staphylococcal DNA cleaved with the restriction endonuclease BgIII: Lane (a) lambda phage DNA cleaved with HindIII as standards with fragment sizes in $\mathrm{Kb}$ shown on the left; (b) pSK1; (c) pSK9; (d) pSK 14; (e) pSK16. pSK1 and pSK16 were prepared from laboratory-derived transferrants, whereas pSK 9 and pSK 14 were isolated from their clinical host strains (table I) which each carry two plasmids. In both cases, the additional plasmid was identified as pSK 3 (which does not possess a $B g I I I$ site); the ccc and oc forms of pSK3 appear in lanes c and d as intense bands of DNA. B. Autoradiograph of the gel shown in (A) after hybridisation with the $0.9-\mathrm{Kb}$ EcoRI-EcoRV fragment of pSK 407. No homologous sequences were detected in lanes $c$ and $\mathrm{d}$ (see text).

Kb EcoRI-EcoRV DNA fragment of pSK407 was considered suitable for use as a $d f r A$-specific probe.

\section{Trimethoprim resistance in coagulase-negative staphylococci}

Screening of 164 clinical isolates of multiresistant coagulase-negative staphylococci showed that 71 strains $(43 \%)$ were resistant to trimethoprim 50 $\mathrm{mg} / \mathrm{L}$. For $63(89 \%)$ of these 71 resistant strains, the MIC of trimethoprim was $100 \mathrm{mg} / \mathrm{L}$, whereas the MIC for the other eight $(11 \%)$ isolates was
$>1000 \mathrm{mg} / \mathrm{L}$. Plasmid elimination and transfer studies failed to demonstrate a plasmid locus for the $\mathrm{Tp}_{(\mathrm{H})}^{\mathrm{r}}$ determinant in these strains, of which six were identified as $S$. epidermidis and two as $S$. hominis type I.

\section{Hybridisation analysis of trimethoprim-resistant coagulase-negative staphylococci}

Rapidly-isolated DNA from four of the $\mathrm{Tp}^{\mathrm{r}}(\mathrm{H})$ strains of coagulase-negative staphylococci, and from one representative $S$. aureus strain harbouring pSK1 (SK 429), was analysed by agarose gel electrophoresis (fig. 3A), transferred to nitrocellulose and then hybridised with the radiolabelled 0.9$\mathrm{Kb}$ EcoRI-EcoRV fragment from plasmid pSK 407 (fig. 3B). Three bands of DNA in strain SK47 (fig.
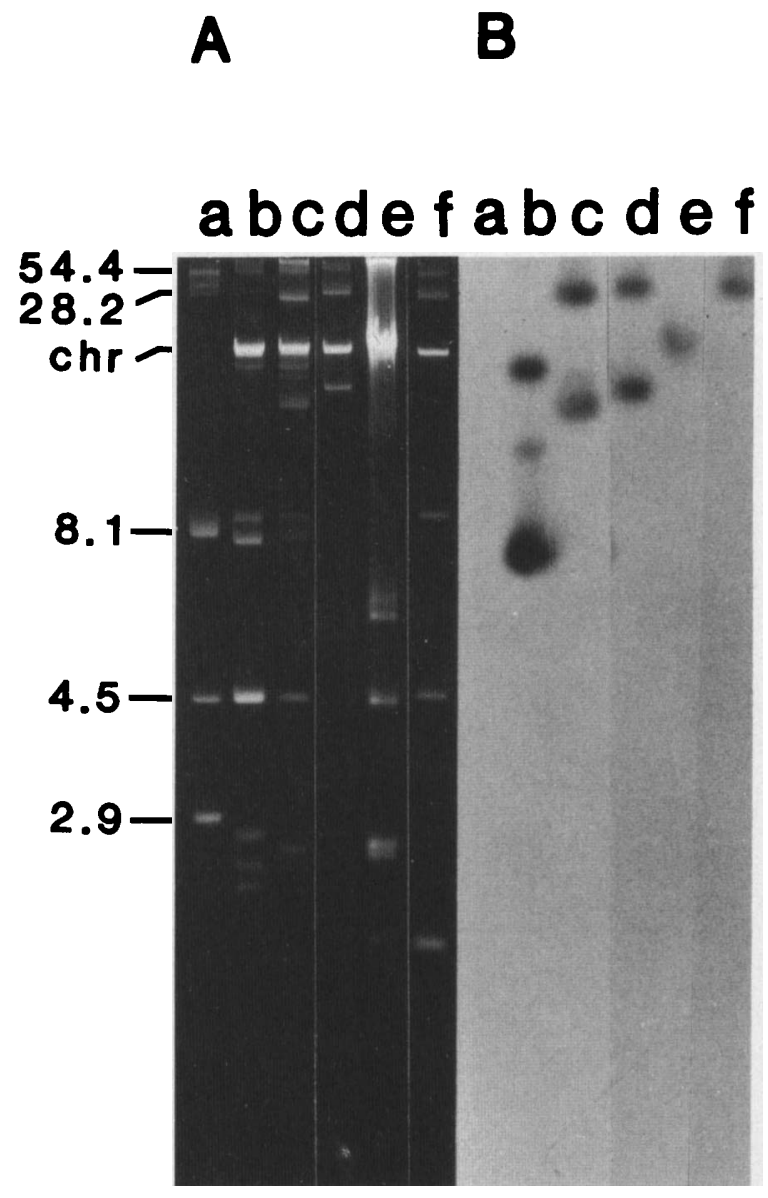

Fig. 3. A. Agarose gel $(1 \% \mathrm{w} / \mathrm{v})$ electrophoresis of rapidlyisolated DNA from strains of coagulase-negative staphylococci resistant to high levels of trimethoprim (MIC>1000 mg/L): Lane (a) plasmid standards with sizes in $\mathrm{Kb}$ shown on the left; (b) SK47; (c) SK76; (d) SK400; (e) SK683; (f) SK429-S. aureus (Lyon et al., 1983). B. Autoradiograph of the gel in $\mathbf{A}$ after hybridisation with the $\mathrm{Tp}_{(\mathrm{H})}^{\mathrm{r}}{ }^{- \text {specific probe. }}$ 
3B, lane b), which were presumed to have corresponded to the covalently closed circular (ccc), open circular (oc) and linear forms of a 7.9-Kb plasmid present in this isolate, hybridised with the probe DNA. Plasmids of different sizes in strains SK76 $(15.5 \mathrm{~Kb})$ and SK $400(17.5 \mathrm{~Kb})$, and the presumptive chromosomal material of SK683, also demonstrated homology with the $d f r A$-specific probe (fig. 3B, lanes c, d, and e).

\section{Dihydrofolate reductases encoded by trimethoprim- resistance genes}

The plasmid-encoded dihydrofolate reductases from strains SK76, SK47 and SK400 were very similar to one another and to the chromosomallyencoded enzyme from strain SK683 (table II). However, the specific activity of the chromosomal dihydrofolate reductase from SK 683 was very much lower than that from the other three strains. All four enzymes had properties similar to those of the type $\mathrm{Sl}$ dihydrofolate reductase encoded by $S$. aureus plasmid pSK 1 , including a remarkably high affinity for methotrexate. The small variations in ID50 values for trimethoprim are unlikely to be significant, especially when they are considered in conjunction with the $\mathrm{Ki}$ results for trimethoprim. The type S1 dihydrofolate reductase differed from the chromosomal enzyme in S. aureus NCTC 6571 and was also distinct from the enzyme in the trimethoprim-sensitive S. epidermidis strain SK 360 (table II).

\section{Discussion}

Over half the strains of MRSA isolated in
Australia harbour a $20-42-\mathrm{Kb}$ plasmid that belongs to a family of structurally-related plasmids which includes pSK 1, pSK 4, pSK8, pSK9, pSK14, pSK 16 and pSK17 (Gillespie et al., 1987b; Lyon et al., 1984a; Lyon and Skurray, unpublished data). In this study, a $0.9-\mathrm{Kb}$ fragment located within the $2 \cdot 75-\mathrm{Kb} B g / \mathrm{II}$ fragment of $\mathrm{pSK} 1$ was used as a $d$ fr $A$-specific probe. Homologous fragments of $2.75 \mathrm{~Kb}$ were also present in the $B g / \mathrm{II}$ digestion profiles of other $S$. aureus plasmids to which the $\mathrm{Tp}^{\mathrm{r}}{ }_{(\mathrm{H})}$ phenotype had previously been assigned by plasmid elimination and transfer experiments. As expected, those $S$. aureus plasmids that did not mediate $T \mathrm{p}_{(\mathrm{H})}^{\mathrm{r}}$ failed to hybridise with the probe DNA. On this basis, isolates of $\mathrm{Tp}^{\mathrm{r}}{ }_{(\mathrm{H})}$ coagulasenegative staphylococci were examined for the presence of DNA sequences homologous to the $S$. aureus $\mathrm{Tp}^{\mathrm{r}}{ }_{(\mathrm{H})}$ determinant. Three isolates of coagulase-negative staphylococci carried plasmid DNA which hybridised with the probe DNA and, in a fourth strain, the probe bound to DNA which formed a band at the position appropriate to chromosomal DNA. The relatively low DHFR activity associated with this fourth strain suggests that the gene was located on a low copy-number replicon as would be expected for the chromosome. Together, these results suggest that an identical $\mathrm{Tp}^{\mathrm{r}}{ }_{(\mathrm{H})}$ determinant was present among some Australian isolates of $S$. aureus and coagulase-negative staphylococci and we believe this to be the first indication that the $S$. aureus $d$ fr $A$ determinant may be present at both plasmid and chromosomal loci in coagulase-negative staphylococci.

The interspecies dissemination of such a $\mathrm{Tp}^{\mathrm{r}}{ }_{(\mathrm{H})}$ determinant may have occurred by plasmid transfer. Archer et al. (1986) showed that conjugative

Table II. Dihydrofolate reductases encoded by plasmids and the chromosome in $S$. aureus and coagulase-negative staphylococci

\begin{tabular}{|c|c|c|c|c|c|c|c|c|}
\hline \multicolumn{2}{|c|}{ Source of enzyme } & $\begin{array}{l}\text { Specific } \\
\text { activity* }\end{array}$ & $\mathbf{M}_{\mathbf{r}}$ & $\begin{array}{c}\text { Tp ID50 } \\
\mu \mathrm{M}\end{array}$ & $\begin{array}{c}\text { MtxID50 } \\
\mu_{\mathrm{M}}\end{array}$ & $\begin{array}{c}\text { TD50 } \\
\min \end{array}$ & $\begin{array}{c}\text { DHF Km } \\
\mu_{\mathrm{M}}\end{array}$ & $\underset{\mu \mathrm{M}}{\mathrm{Tp} \mathrm{Ki}}$ \\
\hline \multicolumn{9}{|c|}{ Tp-sensitive strains (chromosomal) } \\
\hline S. aureus & NCTC 6571 & $14 \cdot 8$ & 21600 & $0 \cdot 04$ & 0.0025 & $>12 \cdot 0$ & $80 \cdot 0$ & 0.0065 \\
\hline S. epidermidis & SK 360 & $8 \cdot 2$ & 22600 & 0.065 & $0 \cdot 00023$ & $>12 \cdot 0$ & $4 \cdot 7$ & 0.0033 \\
\hline \multicolumn{9}{|c|}{ Tp-resistant strains (plasmid) } \\
\hline S. aureus & pSK 1 (type S1) $\dagger$ & $39 \cdot 3$ & 19700 & $50 \cdot 0$ & 0.002 & $>12 \cdot 0$ & $10 \cdot 8$ & $11 \cdot 6$ \\
\hline S. epidermidis & SK $76+$ & $27 \cdot 1$ & 19300 & $15 \cdot 0$ & 0.004 & $>12 \cdot 0$ & $6 \cdot 2$ & $6 \cdot 3$ \\
\hline & SK $47+$ & $51 \cdot 2$ & 20200 & $56 \cdot 0$ & 0.006 & $>12 \cdot 0$ & $4 \cdot 2$ & 4.5 \\
\hline $\begin{array}{l}\text { S. hominis I } \\
\text { (Chromosomal) }\end{array}$ & SK400† & $101 \cdot 0$ & 19900 & $14 \cdot 8$ & 0.0023 & $>12 \cdot 0$ & $12 \cdot 0$ & $3 \cdot 8$ \\
\hline S. epidermidis & SK683 & $7 \cdot 7$ & 19500 & $60 \cdot 0$ & 0.004 & $>12 \cdot 0$ & $8 \cdot 1$ & $9 \cdot 0$ \\
\hline
\end{tabular}

* =nmoles dihydrofolate reduced $/ \mathrm{min} / \mathrm{mg}$ of protein $+\uparrow=$ plasmid-mediated enzymes; $\mathrm{Mtx}=$ Methotrexate, $\mathrm{Tp}=\mathrm{Trimethoprim}$; $\mathrm{DHF}=$ Dihydrofolate; TD50 = Time taken for the enzyme to lose half its activity at $45^{\circ} \mathrm{C}$; ID50 $=$ Concentration inhibiting $50 \%$ of enzyme activity. 
plasmids bearing homologous trimethoprim resistance genes could be transferred between $S$. aureus and $S$. epidermidis. In contrast, none of the Australian isolates of $\mathrm{Tp}_{(\mathrm{H})}^{\mathrm{r}}$ coagulase-negative staphylococci were able to transfer plasmid-borne $\mathrm{Tp}^{\mathrm{r}}{ }_{(\mathrm{H})}$ to $S$. aureus in mixed cultures or by transformation. Furthermore, the pSK1-family of $S$. aureus $\mathrm{Tp}_{(\mathrm{H})}^{\mathrm{r}}$ plasmids were all larger than the genotypically-similar plasmids detected in coagulase-negative staphylococci; the structural relationships between the $\mathrm{Tp}^{\mathrm{r}}{ }_{(\mathrm{H})}$ plasmids from the different staphylococcal species are currently being investigated. Alternatively, the spread of a single $T \mathrm{p}^{\mathrm{r}}(\mathrm{H})$ determinant among the staphylococci may have occurred by recombination between largely dissimilar plasmids or between plasmid and chromosomal DNA. High-level resistance to trimethoprim has hitherto been described as a resistance determinant $(d f r A)$ encoded for only by plasmids of the pSK1 family in Australian isolates of $S$. aureus (Tennent et al., 1985; Lyon et al., 1986). However, the same determinant appears to be present on plasmids unrelated to the pSK 1 family in $S$. aureus isolates from North America (Coughter et al., 1987) and, in this report, we have shown that $d f r A$ may be present on different replicons, including the chromosome, in coagulase-negative staphylococci. These results suggest that this staphylococcal gene can be translocated. Indeed, preliminary data have shown the $\mathrm{Tp}^{\mathrm{r}}{ }_{(\mathrm{H})}$ region of $\mathrm{pSK} 1$ to be flanked by directly repeated copies of the insertion sequence IS 257 (Gillespie et al., 1987a; Lyon and Skurray, 1987). We have designated the putative trimethoprimresistance transposon Tn4003 (Lyon and Skurray, 1987) and are presently screening DNA from the

\section{REFERENCES}

Amyes S G B, Smith J T 1974 R-factor trimethoprim resistance mechanism: an insusceptible target site. Biochemical and Biophysical Research Communications 58:412-418.

Archer G L, Coughter J P, Johnston J L 1986 Plasmid-encoded trimethoprim resistance in staphylococci. Antimicrobial Agents and Chemotherapy $29: 733-740$.

Barth P T, Datta N, Hedges R W, Grinter N J 1976 Transposition of a deoxyribonucleic acid sequence encoding trimethoprim and streptomycin resistance from R483 to other replicons. Journal of Bacteriology 125 : 800-810.

Coughter J P, Johnston J L, Archer G L 1987 Characterization of a staphylococcal trimethoprim resistance gene and its product. Antimicrobial Agents and Chemotherapy 31 : 10271032.

Daniels D L, Schroeder J L, Szybalski W, Sanger F, Blattner F R 1983 A molecular map of coliphage lambda. In: Hendrix R W et al. (eds) Lambda II, Cold Spring Harbor Laboratory, Cold Spring Harbor, New York, pp 469-517.

Gillespie M T, Lyon B R, Loo L S L, Matthews P R, Stewart
$\mathrm{Tp}^{\mathrm{r}}{ }_{(\mathrm{H})}$ coagulase-negative staphylococci for the presence of IS 257 sequences.

The trimethoprim-resistance gene of pSK1 encodes the production of the type S1 dihydrofolate reductase which is quite unlike the plasmid enzymes of gram-negative bacteria (Young and Amyes, 1986; Young et al., 1987). However, the degree of insusceptibility to trimethoprim of the type S1 DHFR is very similar to the type 1 enzyme. The type I enzyme accounts for the majority of plasmidborne trimethoprim resistance in gram-negative organisms. The gene for this enzyme resides on a transposon (Barth et al., 1976) but the level of resistance to trimethoprim may also have some selective advantage. If this is so, the gene encoding the $\mathrm{Sl}$ enzyme may be equally successful in grampositive bacteria.

The presence of common, or closely related, trimethoprim-resistance determinants in S. aureus and coagulase-negative staphylococci strongly suggests that interspecies exchange of genetic material has occurred in vivo among Australian isolates of staphylococci. How such transfer occurs, and which species acts as the source of resistance determinants, are unknown. The transfer of antibiotic resistance from coagulase-negative staphylococci to $S$. aureus on skin in vivo (Jaffe et al., 1980; Naidoo and Noble, 1981) suggests that transfer may have occurred in the natural habitat of these organisms under selective pressure of antimicrobial use.

We thank M. Gillespie for useful discussions, L. Messerotti for technical assistance and $\mathrm{S}$. Ferguson for the identification of some of the strains. This work was supported by a Project Grant from the National Health and Medical Research Council of Australia and Wellcome Trust Grant no. 16376/1.5.
P R, Skurray R A $1987 a$ Homologous direct repeat sequences associated with mercury, methicillin, tetracycline and trimethoprim resistance determinants in Staphylococcus aureus. FEMS Microbiology Letters 43: 165-171.

Gillespie M T, Lyon B R, Messerotti L J, Skurray R A $1987 b$ Chromosome- and plasmid-mediated gentamicin resistance in Staphylococcus aureus encoded by Tn4001. Journal of Medical Microbiology 24:139-144.

Gillespie M T, May J W, Skurray R A 1984 Antibiotic susceptibilities and plasmid profiles of nosocomial methicillin-resistant Staphylococcus aureus: a retrospective study. Journal of Medical Microbiology 17:295-310.

Gillespie M T, May J W, Skurray R A 1986 Plasmid-encoded resistance to acriflavine and quaternary ammonium compounds in methicillin resistant Staphylococcus aureus. FEMS Microbiology Letters 34:47-51.

Hamilton-Miller J M T, Gooding A, Brumfitt W 1981 Resistance to trimethoprim in 1978-79 compared with 1973-75. Journal of Clinical Pathology 34:439-442.

Jaffe H W, Sweeney H M, Nathan C, Weinstein R A, Kabins S A, Cohen S 1980 Identity and interspecific transfer of 
gentamicin-resistance plasmids in Staphylococcus aureus and Staphylococcusepidermidis. Journal of Infectious Diseases 141 : 738-747.

Kloos W E, Schleifer K H 1975 Simplified scheme for routine identification of human Staphylococcus species. Journal of Clinical Microbiology 1:82-88.

Lacey R W 1975 Antibiotic resistance plasmids of Staphylococcus aureus and their clinical importance. Bacteriological Reviews 39: $1-32$

Lyon B R, Gillespie M T, Byrne M E, May J W, Skurray R A 1987 Plasmid-mediated resistance to gentamicin in Staphylococcus aureus: the involvement of a transposon. Journal of Medical Microbiology 23:101-110.

Lyon B R, Iuorio J L, May J W, Skurray R A 1984a Molecular epidemiology of multiresistant Staphylococcus aureus in Australian hospitals. Journal of Medical Microbiology 17:79-89.

Lyon B R, May J W, Skurray R A 1983 Analysis of plasmids in nosocomial strains of multiple-antibiotic-resistant Staphylococcus aureus. Antimicrobial Agents and Chemotherapy 23:817-826.

Lyon B R, May J W, Skurray R A $1984 b$ Tn4001: a gentamicin and kanamycin resistance transposon in Staphylococcus aureus. Molecular and General Genetics 193:554-556.

Lyon B R, Skurray R A 1987 Antimicrobial resistance of Staphylococcus aureus: genetic basis. Microbiological Reviews 51 : 88-134.

Lyon B R, Tennent J M, May J W, Skurray R A 1986 Trimethoprim resistance encoded on a Staphylococcus aureus gentamicin resistance plasmid: cloning and transposon mutagenesis. FEMS Microbiology Letters 33:189-192.

Maniatis T, Fritsch E F, Sambrook J 1982 Molecular cloning: a laboratory manual. Cold Spring Harbor Laboratory, Cold Spring Harbor, New York.

McDonnell R W, Sweeney H M, Cohen S 1983 Conjugational transfer of gentamicin resistance plasmids intra- and interspecifically in Staphylococcus aureus and Staphylococcus epidermidis. Antimicrobial Agents and Chemotherapy 23: 151160.
Naidoo J, Noble W C 1981 Transfer of gentamicin resistance between coagulase-negative and coagulase-positive staphylococci on skin. Journal of Hygiene 86: 183-187.

Richardson J F 1983 Frequency of resistance to trimethoprim among isolates of Staphylococcus epidermidis and Staphylococcus saprophyticus. Journal of Antimicrobial Chemotherapy 11 : $163-167$.

Smith J T, Amyes S G B 1984 Bacterial resistance to antifolate chemotherapeutic agents mediated by plasmids. British Medical Bulletin 40:42-46.

Smith G E, Summers M D 1980 The bidirectional transfer of DNA and RNA to nitrocellulose or diazobenzyloxymethylpaper. Analytical Biochemistry 109:123-129.

Tennent J M, Lyon B R, Gillespie M T, May J W, Skurray R A 1985 Cloning and expression of Staphylococcus aureus plasmid-mediated quaternary ammonium resistance in Escherichia coli. Antimicrobial Agents and Chemotherapy 27:79-83.

Tennent J M, May J W, Skurray R A 1984 Multiple antibiotic resistance in Staphylococcus aureus and Staphylococcus epidermidis: plasmids in strains associated with nosocomial infection. Pathology 16:250-255.

Tennent J M, May J W, Skurray R A 1986 Characterisation of chloramphenicol resistance plasmids of Staphylococcus aureus and $S$. epidermidis by restriction enzyme mapping techniques. Journal of Medical Microbiology 22:79-84.

Townsend D E, Ashdown N, Greed L C, Grubb W B 1984 Transposition of gentamicin resistance to staphylococcal plasmids encoding resistance to cationic agents. Journal of Antimicrobial Chemotherapy 14:115-124.

Young H-K, Skurray R A, Amyes S G B 1987 Plasmid-mediated trimethoprim-resistance in Staphylococcus aureus: characterization of the first gram-positive plasmid dihydrofolate reductase (type S1). Biochemical Journal 243: 309-312.

Young H-K, Amyes S G B 1986 A new mechanism of plasmid trimethoprim resistance: characterization of an inducible dihydrofolate reductase. Journal of Biological Chemistry 261:2503-2505. 